\title{
Percentage of mangrove canopy coverage and community structure in Batanta Island and Salawati Island, Raja Ampat District, West Papua Province
}

\author{
Joshian N.W. Schaduw \\ Marine Science Study Program, Faculty of Fisheries and Marine Science, Sam Ratulangi University (UNSRAT), Manado 95119 \\ Email: schaduw@unsrat.ac.id
}

Received: 25 April 2020 - Revised: 20 May 2020 -Accepted: 21 May 2020

\begin{abstract}
The research aimed at monitoring the condition of mangrove communities in Batanta Island and Salawati Island, Raja Ampat District, West Papua Province. It used method developed by the Indonesian Institute of Sciences Research Center for Oceanography (P2O LIPI). Method in determining the percentage for the coverage of mangrove communities used a hemispherical photography and the data analysis used ImageJ software in excel tabulation. The result showed that mangrove canopy coverage has decreased from $85.73 \%$ in 2017 to $84.14 \%$ in 2018. Since the observations in 2015 , the percentage of mangroves had no significant change. In average the percentage increased as much as $3.45 \%$ from $75.09 \%$ in 2015 to $78.54 \%$ in 2016. Moreover, it increased again by $7.20 \%$ in $2017(85.73 \%)$. It indicates that the average change percentage of mangroves is not significant, and it can be concluded that the mangrove ecosystem in this area does not degrade significantly and has a good growth rate. The average density value was 1254.3 trees per hectare in the period of 2016-2018 or it increased to about $16.5 \%$ since 2015. The number of species found at the observation site were 5 species (Rhizophora mucronata, Rhizophora apiculata, Bruguiera gymnorrhiza, Sonneratia alba, and Xylocarpus granatum) scattered in eight observation stations. From these results it can be concluded that mangrove condition at the research location is stable and gets support for the survival of biota associated therein.
\end{abstract}

Keywords: mangrove; community structure; Batanta; Salawati; Raja Ampat

\section{INTRODUCTION}

Raja Ampat Archipelago is in the heart of the world's Coral Triangle and is in the center of the richest tropical marine biodiversity in the world today. This area is in the westernmost part of the mother island of Papua in Indonesia. These stretch over the total area of approximately 4.6 million hectares. Not only fish species, Raja Ampat Islands are also rich in diversity of coral reefs, seagrass beds, mangrove forests, and rocky cliff beaches. Another interesting potential is the development of ecotourism businesses and the region has also been proposed as a World Heritage Site by the Government of Indonesia. This great potential, if properly managed and utilized, will be able to prosper the people who live in coastal areas and small islands. However, if the coastal areas and small islands are not managed properly, there will be a significant degradation of ecosystems.

In the period of 2015-2018, Coral Reef Rehabilitation and Management-Coral Triangle Initiative (Coremap-CTI) Project held by the Indonesian Institute of Sciences Research Center for Oceanography (P2O LIPI) has monitored the health of coral reef, seagrass and mangrove ecosystems in the waters of Salawati Island and Batanta Island.

Raja Ampat was declared as a new district in 2003. It was based on Law No. 26 on the Establishment of Sarmi District, Kerom District, South Sorong District, and Raja Ampat District which was ratified on May 3, 2002. Raja Ampat District is the result of Sorong District expansion and it is one of the 14 new established districts in Papua and is part of West Papua Province. The district consists of 4 large islands, i.e. Waigeo, Batanta, Salawati and Misool Island with more than 600 small islands. The district central government is in Waisai, Waigeo District about 36 miles from Sorong City. The district government has effectively functioned since September 16, 2005. From the aspect of geoeconomics' and geopolitics, Raja Ampat Islands have an important role as the region directly adjacent to foreign territories. Fani Island is located at the most northernmost of Raja Ampat Islands directly adjacent to the Republic of Palau. As the islands, the district has 1,800 large and small islands, atolls, and takas with total coastline length of $753 \mathrm{kms}$. Of the islands, there are 35 islands having been inhabited. 


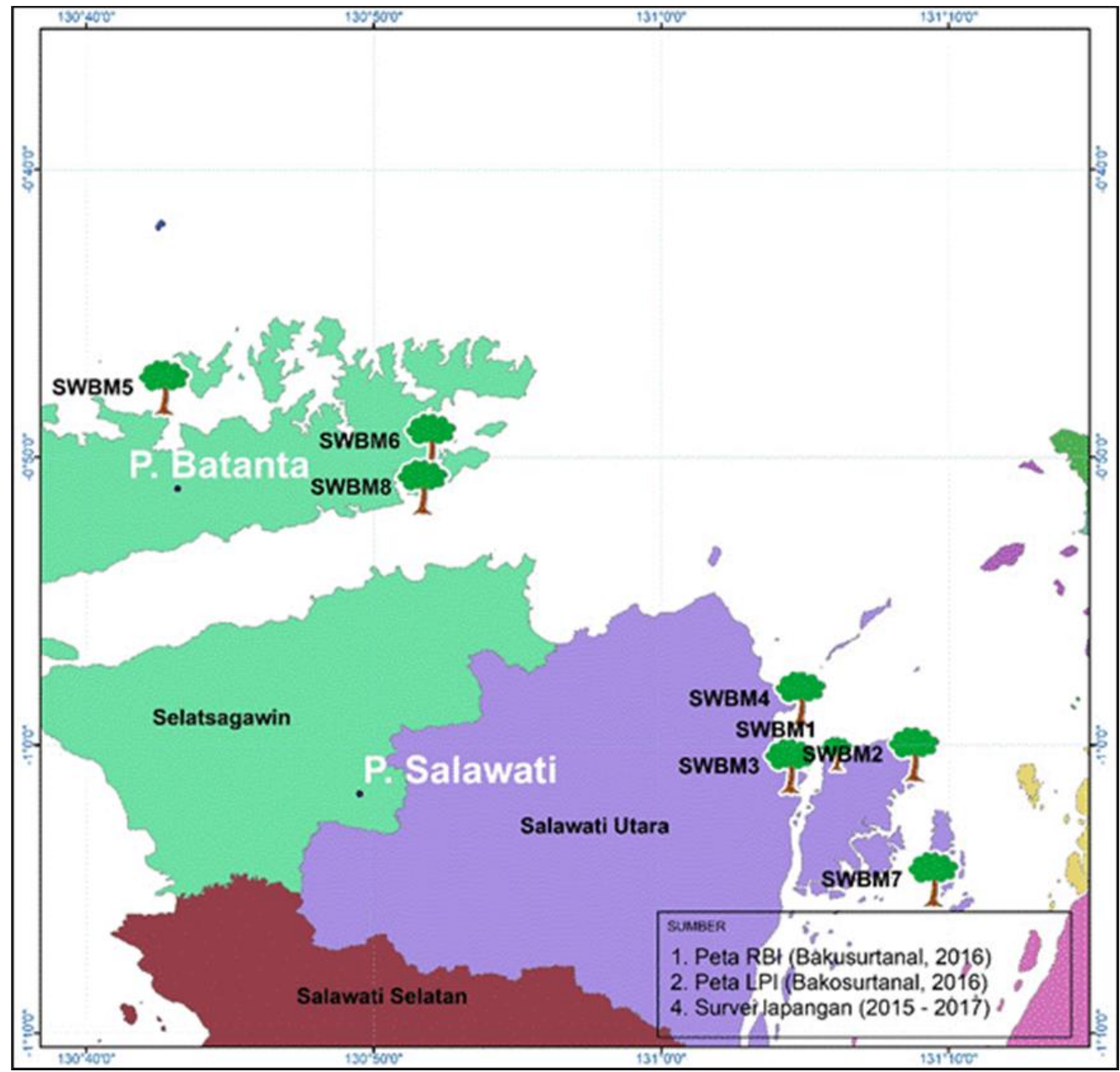

Figure 1. Research location of Batanta Island and Salawati Island, West Papua Province

The ratio of land and water area is 1:6 and the dominant area in the district is waters.

Mangroves are one of the important ecosystems with systemic impacts on small islands, and the degradation of the ecosystems will affect other ecosystems such as coral reefs and seagrasses (Schaduw, 2013). Other benefit of mangroves is as a habitat for gastropods associating in the ecosystem. The research of Djohar et al. (2020) proves that the better the condition of the mangrove ecosystems, the more the abundance of gastropods in the location will grow. By considering the importance of mangrove ecosystems in coastal areas, this research must be carried out. The mangrove research in a kind of sustainability of more complex ecosystem management involving all dimensions (ecology, economy, social, and institution) are required in monitoring and evaluating conservation activities currently and in future years (Schaduw, 2015b).

Because the existence of mangroves in a coastal area is important, the research aims at monitoring the condition of the mangrove communities through a periodic monitoring of the canopy cover and structure of the mangrove communities with the same method and location, therefore the obtained data is not biased and can be used for the benefits of integrated and sustainable coastal resource management.

\section{MATERIALS AND METHODS}

The monitoring of mangrove ecosystems in Batanta and Salawati Island was conducted in the period of 2015 to 2018; three stations in Batanta Island (Arefi Island, Yenanas Village and Amdui Village) and five stations in Wamega Village (Kasim Kecil Island, Kolobo Village, Samate Village, and Kabra Kecil Island) (Figure 1). These observation stations were similar to coordinates and transects which was made in the period of 2015 to 2017 . The substrates at the research location were mud and muddy sand. In such substrate conditions mangrove forests were dominated by Rhizophora species. This is in line with Schaduw (2015a, 2016a) studies on mangrove 
Table 1. Interpretation for status of mangrove condition (Decree of Minister of Environment No. 201, 2004)

\begin{tabular}{llcc}
\hline \multicolumn{2}{c}{ Criteria } & $\begin{array}{c}\text { Coverage } \\
(\%)\end{array}$ & $\begin{array}{c}\text { Density } \\
\text { (trees/ha) }\end{array}$ \\
\hline Good & Dense & $\geq 75 \%$ & $\geq 1500$ \\
& Moderate & $50 \%-75 \%$ & $1000-1500$ \\
Damaged & Sparse & $<50 \%$ & $<1000$ \\
\hline
\end{tabular}

ecosystem in the marine protected area of Blongko Village.

The method used in this research was field survey method, a direct observation in the field on condition of the mangrove ecosystem. The field observations to find out the structure of the mangrove community was done by using quadrant line transect method and image capture to determine percentage of mangrove canopy cover was performed by using hemispherical photography method (Dharmawan and Pramudji, 2014).

The line transect method was carried out by making the perpendicular line from coast to the land in a kind of plots (Cox, 1969 in Abrar et al., 2014). Hemispherical photography method is a technique for characterizing mangrove canopy cover by using photographs in estimating solar radiation and plant characteristics through a remote view lens (Anderson, 1964).

\section{Determination of Research Stations}

The research was conducted in eight stations. At each station two transect lines were established and each transect line consisted of 3 sampling plots. The observation on transect path was started with the perpendicular direction from coastal to the land along the mangroves, and each transect line must represent the research area and every zonation of the existing mangrove forests.

\section{Measurement for Structure of Mangrove Communities and Mangrove Coverage}

The field measurement of mangrove community structure used the quadrant line transect method (Dharmawan and Pramudji, 2014). The percentage of mangrove coverage was calculated using the hemispherical photography method. This technique is relatively new in mangrove forests in Indonesia, and the advantage of this photography method is it easy, more accurate and stronger in evidence (Dharmawan and Pramudji, 2014).

\section{Analysis for Percentage of Mangrove Coverage}

In the hemispherical photography method, the ImageJ was used to analyze the taken photographs. The concept behind this analysis is to separate sky pixels and mangrove coverage. This application is very useful in the image processing (Dharmawan and Pramudji, 2014).

\section{Interpretation for Status of Mangrove Condition}

Data on the analysis of the percentage of canopy cover and community structure of the mangrove are used to describe the status and condition of mangrove forest and they were classified into three categories: sparse, moderate, and dense (Table 1). These categories were based on the Decree of Minister of Environment No. 201 in 2004 regarding the standard of damaged mangrove forest.

\section{RESULTS AND DISCUSSION}

The results of the study on the condition of mangrove vegetation in Batanta Island and Salawati Island, Raja Ampat Islands District covered the percentage of coverage, density, and Importance Value Index (IVI) (Table 2). The highest percentage of the coverage was found at the SWBM05 station in Arefi

Table 2. Research location of mangrove and substrate types (Schaduw, 2019)

\begin{tabular}{|c|c|c|c|c|c|c|}
\hline \multirow{2}{*}{ No } & \multirow{2}{*}{ Stations } & \multirow{2}{*}{ Locations } & \multicolumn{2}{|c|}{ Coordinates } & \multirow{2}{*}{ Substrate Types } & \multirow{2}{*}{$\begin{array}{c}\text { Coverage } \\
\text { Remark }\end{array}$} \\
\hline & & & Longitude & Latitude & & \\
\hline 1 & SWBM01 & Wamega Village/Salawati Island & 131.101 .800 & $-1,00491$ & Mud & Dense \\
\hline 2 & SWBM02 & Kasim Kecil/Salawati Island & 131.146 .330 & $-1,00533$ & Muddy Sand & Dense \\
\hline 3 & SWBM03 & Kalobo Village/Salawati Island & 131.074 .630 & $-1,01217$ & Muddy Sand & Dense \\
\hline 4 & SWBM04 & Samate Village/Salawati Island & 131.080 .640 & $-0,97307$ & Mud & Dense \\
\hline 5 & SWBM05 & Arefi Island/Batanta & 130.711 .476 & $-0,79297$ & Mud & Sporadic \\
\hline 6 & SWBM06 & Amdui Village/ Batanta Island & 130.866 .300 & $-0,82394$ & Mud & Dense \\
\hline 7 & SWBM07 & Kabra Kecil/Salawati Island & 131.157 .520 & $-1,07776$ & Mud & Dense \\
\hline 8 & SWBM08 & Yenanas Village/Batanta Island & 130.861 .370 & $-0,85066$ & Mud & Moderate \\
\hline
\end{tabular}


Schaduw: Percentage of mangrove canopy coverage and community structure in Batanta Island ...

Table 3. Percentage of cover, density, and Importance Value Index (IVI) (Schaduw, 2019)

\begin{tabular}{|c|c|c|c|c|c|c|}
\hline \multirow{2}{*}{ Stations } & \multirow{2}{*}{ Locations } & \multirow{2}{*}{$\begin{array}{l}\text { Total } \\
\text { Types }\end{array}$} & \multirow{2}{*}{$\begin{array}{c}\% \\
\text { Coverage }\end{array}$} & \multirow{2}{*}{ Density } & \multicolumn{2}{|c|}{ Importance Value Index } \\
\hline & & & & & Min & Max \\
\hline SWBM01 & Wamega Village/ Salawati Island & 3 & $\begin{array}{c}77.80 \pm \\
10.07\end{array}$ & $\begin{array}{c}900.00 \pm \\
100.00\end{array}$ & Rm: 76.50 & Ra: 125.88 \\
\hline SWBM02 & Kasim Kecil Island/Salawati Island & 3 & $\begin{array}{c}84.64 \pm \\
2.89\end{array}$ & $\begin{array}{c}1450.00 \pm \\
287.22\end{array}$ & Rm: 29.27 & Ra: 181.41 \\
\hline SWBM03 & Kalobo Village/ Salawati Island & 4 & $\begin{array}{c}82.70 \pm \\
2.88\end{array}$ & $\begin{array}{c}1600.00 \pm \\
458.25\end{array}$ & Ra: 32.35 & Ra: 177.63 \\
\hline SWBM04 & Samate Village/ Salawati Island & 3 & $\begin{array}{c}83.03 \pm \\
5.95\end{array}$ & $\begin{array}{c}866.66 \pm \\
152.75\end{array}$ & Sa: 23.45 & Ra: 193.75 \\
\hline SWBM05 & Arefi Island/Batanta Island & 3 & $\begin{array}{c}88.97 \pm \\
1.71\end{array}$ & $\begin{array}{c}1166.66 \pm \\
225.09\end{array}$ & Bg: 12.58 & Ra: 177.47 \\
\hline SWBM06 & Amdui Village/ Batanta Island & 5 & $\begin{array}{c}86.47 \pm \\
3.59\end{array}$ & $\begin{array}{c}1316.66 \pm \\
147.20\end{array}$ & $\mathrm{Xg}: 8.68$ & $\mathrm{Ra}: 121.50$ \\
\hline SWBM07 & Kabra Kecil Island /Salawati Island & 2 & $\begin{array}{c}86.34 \pm \\
4.13\end{array}$ & $\begin{array}{c}1400.00 \pm \\
451.66\end{array}$ & Ra: 78. 26 & Bg: 221.73 \\
\hline SWBM08 & Yenanas Village/Batanta Island & 4 & $\begin{array}{c}83.17 \pm \\
6.15\end{array}$ & $\begin{array}{c}1333.33 \pm \\
577.35\end{array}$ & Rm: 13.49 & Ra: 170.68 \\
\hline
\end{tabular}

Island, Salawati Island with a total value of $88.97 \%$, and the lowest was at the SWBM01 station in Wamega Village, Salawati Island with a total value of $72.80 \%$. Moreover, the highest mangrove density was shown at the SWBM03 station in Kolobo Village, Salawati Island with total value of 1600 ind/ha and the lowest one was at the SWBM04 station in Samate Village, Salawati Island with total value of $866.66 \mathrm{ind} / \mathrm{ha}$. The species with the highest importance index value at eight observation stations was Rhizophora apiculata, and this condition is similar to mangrove community structure in Nain Island which is located in the conservation area of Bunaken National Park (Schaduw, 2018b). For the
IVI of each observation station it can be seen in Table 3.

Percentage of mangrove coverage in Batanta Island and Salawati Island (from eight stations) in 2018 was $84.14 \%, 1.59 \%$ less than those in 2016 $(85.73 \%)$, and for Batanta Island (three stations) with the percentage of $87.41 \%$ in 2017 which was less $1.21 \%$ than that of $2018(86.20 \%)$ and for Salawati Island (five stations) with the percentage of $84.72 \%$ in 2017 (1.82\% less than of 2018 [82.90\%]) (Fig. 2 and 3$)$.

Based on the Decree of the Minister of Environment No. 201 in 2004, the result of percentage mangrove coverage in Stations 1 to 8 can be categorized into densely covered (> 75\%). In
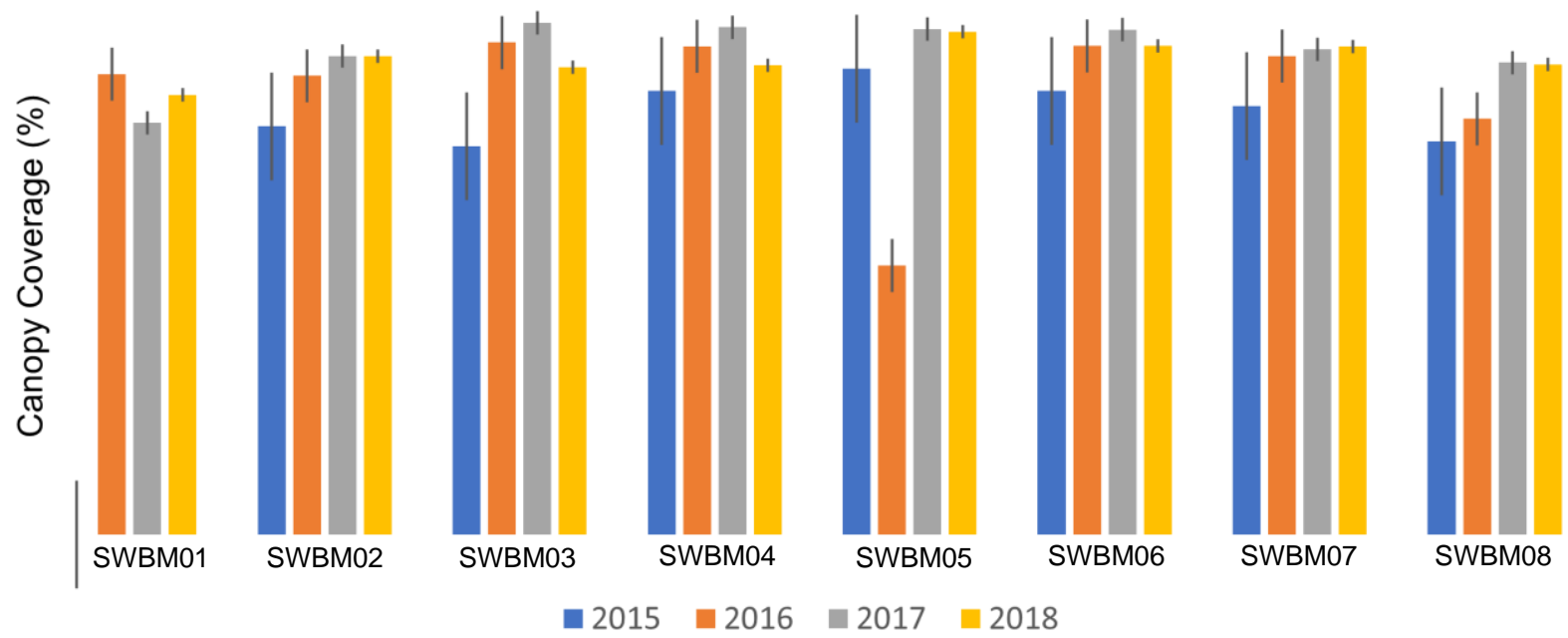

Figure 2. Percentage (\%) of mangrove canopy coverage (Schaduw, 2019). The ANOVA shows that the $p>0.05$; it means that there is no significant difference in the percentage of the canopy coverage in the observation years of 2015-2018 


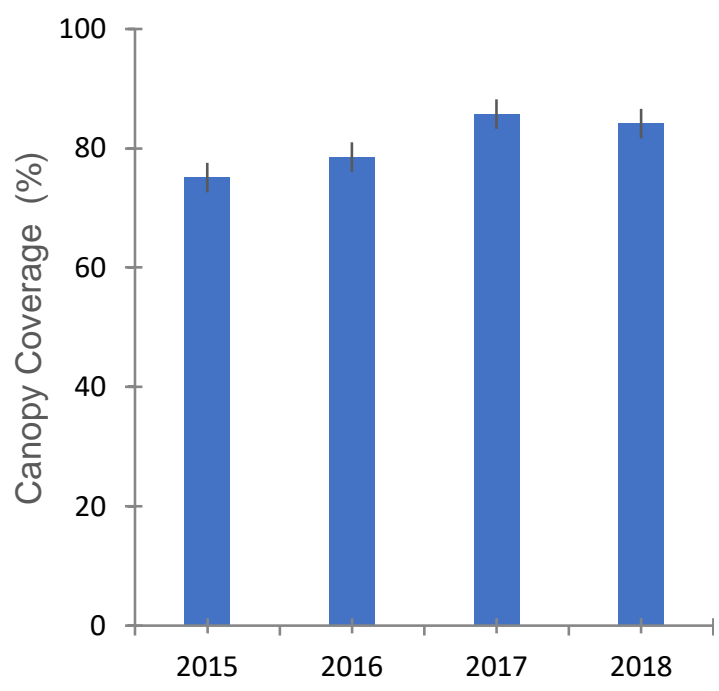

Figure 3. Average mangrove canopy coverage

(Schaduw, 2019)

2017, Station 1 was categorized as moderately covered. Moreover, the results of the density also showed that density value was based on the size of the individuals. Those which are large have the high density, on the contrary those small individuals have the low-density values. The highest density of a species is mainly due to suitable substrate, and the ability to adapt to environmental conditions. Factors that can impact the relatively rare mangrove growth are the condition of the size of tree roots, those which are classified as large can affect the mangrove growth to become less optimal (Agustini et al., 2016).

The percentage of the mangrove coverage in 2016 was higher than that in the previous year. It indicates that the mangrove growth in the research location is good. In other words, there is no significant degradation here. At SWBM05 observation station, a sharp decrease occurred in 2015 and 2016. Some large mangrove trees had died due to the mangrove age. This reduced the percentage of mangrove coverage at the observed station. The average mangrove coverage was $70.5 \%$ in 2015 and it rose to $78.5 \%$ in 2016. It indicates an increase in the coverage presentation of $8 \%$ per year.

The percentage of the mangrove coverage rose in 2016 and it showed that the mangrove growth in this area was relatively good and human destruction activities did not cause damage. At the SWBM05 observation station, the percentage decreased due to the fall of several trees and the mangrove age. From the above analysis it can be concluded that there was an increase in the percentage of the coverage, but it did not have significant meaning. The mangrove ecosystem at the observation stations tends to be stable and good.
The results of the study on the condition of mangrove vegetation in Batanta Island and Salawati Island, Raja Ampat Islands District include the percentage of coverage, density, and IVI. The highest percentage of the coverage was found at the SWBM03 station in Kampung Kolobo, Salawati Island with a total value of $90.54 \%$. It increased as much as $3.53 \%$ compared to that in 2016 (87.02\%). On the other hand, the lowest percentage of the coverage was found in Kampung Wamega Salawati Island with a total value of $72.83 \%$. It differed from that of 2016 when the lowest percentage of the mangrove coverage was found in Arefi Island. The highest percentage of the mangrove density was in Kampung Kolobo observation station, Salawati Island with a total value of 1600 . Otherwise, the lowest value at the SWBM Station 4 in Samate Village, Salawati Island with a total value of 866.66. However, there was no difference in the density in 2016 and 2017.

The percentage of the mangrove coverage in 2017 was higher than that in the previous year. It indicates that the mangrove growth in the research location was quite good, and it can be said that there was no significant degradation at the research location. At the SWBM01 observation station the 2017 data indicates a decrease in the percentage of the mangrove coverage by $8.62 \%$ due to the felling of mangrove trees around the observation stations.

At the SWBM05 observation station, a sharp decrease in the percentage occurred in 2015 and 2016. Several large mangrove trees and their branches had died due to the mangrove age, and it reduced the presentation of mangrove coverage at the station. The percentage rose to $89.43 \%$ in 2017 after correcting the observation stations was made to the sign direction in 2016. The signs (spray paint on the tree) was changed to the left in 2016 and the right in 2017. It was carried out after receiving information from local boatmen about the sign direction made in 2015. The different direction of the plot occurred in 2015 because the trees that became the benchmark were not marked or if it was made, there was only three. Moreover, the following year all trees were marked to facilitate the observation activities. After correction, the change of the coverage percentage in 2015 and 2017 was found to be insignificant. Average percentage of the mangrove coverage showed an increase but insignificant in the period of 2015-2018.

From average mangrove coverage, the percentage of the coverage amounted to $75.8 \%$ in 2015 and $78.5 \%$ in 2016, it indicated an increase in the coverage presentation of $3.44 \%$ in one year. On the other hand, average coverage percentage reached 
Table 4. Mangrove types at each observation station (Schaduw, 2019)

\begin{tabular}{lcccccccc}
\hline \multicolumn{1}{c}{ Mangrove types } & 1 & 2 & 3 & 4 & 5 & 6 & 7 & 8 \\
\hline Rhizophora mucronata & $\mathrm{x}$ & $\mathrm{x}$ & $\mathrm{x}$ & & $\mathrm{x}$ & $\mathrm{x}$ & & $\mathrm{x}$ \\
Rhizophora apiculata & $\mathrm{x}$ & $\mathrm{x}$ & $\mathrm{x}$ & $\mathrm{x}$ & $\mathrm{x}$ & $\mathrm{x}$ & $\mathrm{x}$ & $\mathrm{x}$ \\
Bruguiera gymnorrhiza & $\mathrm{x}$ & $\mathrm{x}$ & $\mathrm{x}$ & $\mathrm{x}$ & $\mathrm{x}$ & $\mathrm{x}$ & $\mathrm{x}$ & $\mathrm{x}$ \\
Sonneratia alba & & & $\mathrm{x}$ & $\mathrm{x}$ & & $\mathrm{x}$ & & $\mathrm{x}$ \\
Xylocarpus granatum & & & & & & $\mathrm{x}$ & & \\
\hline
\end{tabular}

$85.73 \%$ in 2017 , and it increased $7.20 \%$. In the next year, the average value decreased to $84.14 \%$ because local climate change and wind/storm season occasionally occurred at the observation stations.

Indriyanto (2006 in Agustini et al., 2016) argues that the dominant species in a plant community will have a high IVI, therefore the most dominant species will have the greatest IVI. Furthermore, Raymond et al. (2010) stated that the species with the high IVI means to have a cumulative value of greater control over their habitat. This type will be superior in utilizing the existing resources or it is more able to adjust to the local environment.

\section{Mangrove Types}

The number of mangrove species at each observation station varies both in number and types. The SWBM06 observation station has the highest number of mangrove species, i.e. five species including Rhizophora mucronata, Rhizophora apiculata, Bruguiera gymnorrhiza, Sonneratia alba, and Xylocarpus granatum (Table 4). Moreover, the SWBM07 observation station only has two types of mangroves, i.e. Rhizophora apiculata and Bruguiera gymnorrhiza. Total number of species found in the monitoring results in 2018 remained similar to 2017 due to the same observation plot positions. It differs from the number of species in Bunaken Island in Bunaken National Park. The area of the island's mangrove ecosystem reaches 71.57 hectares. The island has five mangrove species, i.e. Soneratia alba, Avicennia marina, Xylocarpus granatum, Rhizophora apiculata, and Bruguiera gymnorrhiza, which are divided into four families, i.e. Sonneratiaceae, Avicenniaceae, Meliaceae, and Rhizophoraceae (Schaduw, 2016b).

\section{Mangrove Density}

Average density value was 1051.88 individuals per hectare in 2015 , and in the period of 2016-2018 it reached 12542.5 individuals per hectare (Fig. 4). The condition of mangrove density in each observation stations in Batanta and Salawati Island has not significantly changed. The absence of mangrove cutting and fallen trees makes the condition stable. The results of the above analysis show the $\mathrm{P}$ value of $0.30>5 \%$, it can be concluded that there is no real difference in the condition of mangrove density in the period of 2015-2018.

\section{CONCLUSION}

From this study, it can be concluded that the mangrove ecosystem in this area does not experience significant degradation and it has a good growth rate. The average density value is 1254.3 trees/ha in the period of 2016-2018 or it has increased around 16.5 since 2015. This increase in density is not due to the growth of new plants, but it was contributed by additional number of plots and samples taken in the period of 2016-2018. The number of species found at the observation stations were 5 species (Rhizophora

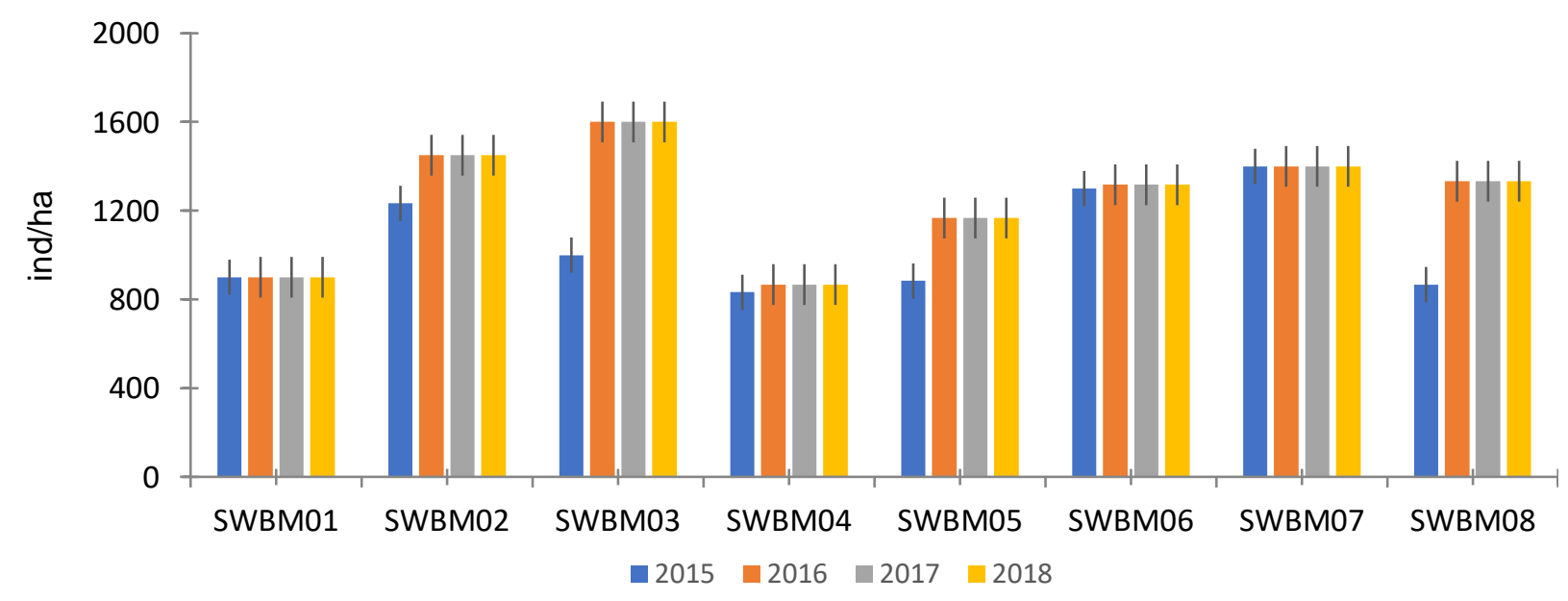

Figure 4. Mangrove Density (Schaduw, 2019) 
mucronata, Rhizophora apiculata, Bruguiera gymnorrhiza, Sonneratia alba, and Xylocarpus granatum), scattered in eight observation stations.

Acknowledgment. The author thanks the COREMAP-CTI of the Indonesian Institute of Sciences, Research Center for Oceanography (P2O LIPI) for the fund. The author also thanks the Ministry of Technology Research and Higher Education, Research and Community Service Institute (LPPM) of Sam Ratulangi University (UNSRAT), and the Dean of the Faculty of Fisheries and Marine Science of UNSRAT, who had facilitated and supported the research.

\section{REFERENCES}

ABRAR, M., GIYANTO., SIRINGORINGO, R.M., EDRUS, I.N., ARBI, U.Y., SIHALOHO, H.F., SALATALOHI, A. and SUTIADI (2014) Laporan Monitoring (Baseline) Kesehatan Ekosistem Terumbu Karang dan Ekosistem Terkait Lainnya di Taman Wisata Perairan Pulau Pieh dan Sekitarnya, Sumatera Barat. Pusat Penelitian Oseanografi. Jakarta: Lembaga Ilmu Pengetahuan Indonesia.

AGUSTINI, N.T., TA'ALADIN, Z. and PURNAMA, D. (2016) Struktur komunitas mangrove di Desa Kahyapu Pulau Enggano. Jurnal Enggano, 1 (1), pp.19-31.

ANDERSON, M.C. (1964) Studies of the woodland light climate: I. The photographic computation of light condition. Journal of Ecology, 52 (1), pp. 27-41.

DHARMAWAN, I.W.E. and PRAMUDJI (2014) Panduan Monitoring Status Ekosistem Mangrove. CRITC COREMAP-CTI. Pusat Penelitian Oseanografi. Jakarta: Lembaga Ilmu Pengetahuan Indonesia.

DJOHAR, M.A., BONEKA, F.B., SCHADUW, J. N.W., MANDAGI, S.V., ROEROE, K.A. and SUMILAT, D.A. (2020) Marine waste, analysis and abundance of gastropods in mangrove ecosystem Tongkaina, North Sulawesi. Jurnal Ilmiah Platax, 8 (1), pp. 15-23.
RAYMOND, G.P., HARAHAP, N. and SOEMARNO (2010) Pengelolaan hutan mangrove berbasis masyarakat di Kecamatan Gending, Probolinggo. Agritek, 18 (2), pp. 185200.

SCHADUW, J.N.W. (2013) Small island mitigation based on mangrove ecosystem management in Bunaken National Park. Aquatic Science \& Management, 1 (2), pp. 133-142.

SCHADUW, J.N.W. (2015a) Bioekologi mangrove daerah perlindungan laut berbasis masyarakat Desa Blongko Kecamatan Sinonsayang Kabupaten Minsel Provinsi Sulut. Jurnal LPPM UNSRAT Bidang Sains dan Teknologi, 2 (1), pp. 89-102.

SCHADUW, J.N.W. (2015b) Keberlanjutan pengelolaan ekosistem mangrove Pulau Mantehage, Kecamatan Wori, Kabupaten Minahasa Utara, Provinsi Sulawesi Utara. Jurnal LPPM UNSRAT Bidang Sains dan Teknologi, 2 (2), pp. 60-70.

SCHADUW, J.N.W. (2016a) Evaluasi pengelolaan ekosistem mangrove pada daerah perlindungan laut Desa Blongko Kecamatan Sinonsayang Kabupaten Minahasa Selatan Provinsi Sulawesi Utara. Jurnal Spasial, 16 (2), pp. 27-38.

SCHADUW, J.N.W. (2016b) Kondisi ekologi mangrove Pulau Bunaken Kota Manado Provinsi Sulawesi Utara. Jurnal LPPM UNSRAT Bidang Sains dan Teknologi, 3 (2), pp. 64-74.

SCHADUW, J.N.W. (2018a) Distribusi dan karakteristik kualitas perairan ekosistem mangrove Pulau Kecil Taman Nasional Bunaken. Majalah Geografi Indonesia, 32 (1), pp. 40-49.

SCHADUW, J.N.W. (2018b) Struktur komunitas dan keberlanjutan pengelolaan ekosistem mangrove pulau-pulau kecil (kasus pada Pulau Nain Kabupaten Minahasa Utara Provinsi Sulawesi Utara). Jurnal Ilmu Lingkungan, 16 (2), pp. 120-129.

SCHADUW, J.N.W. (2019) Struktur komunitas dan persentase penutupan kanopi mangrove Pulau Salawati Kabupaten Kepulauan Raja Ampat Provinsi Papua Barat. Majalah Geografi Indonesia, 33 (1), pp. 26-34. 